\title{
UK scientists threatened with pay freeze
}

London. Thousands of British scientists working in universities and governmentfunded laboratories face the prospect of a pay freeze next year as a result of moves by Kenneth Clarke, the chancellor of the exchequer, to reduce public sector spending.

Clarke announced last week that the government intends to keep the overall salary bill for government employees for the financial year beginning next April to the same level as this year. He added that increases could be paid where there was evidence of productivity gains.

But organizations representing scientists in their salary negotiations with the government point out that this formula means that increases can be paid only where there is a net reduction in staff.

They also claim that a freeze on scientists' salaries conflicts directly with the message of the recent white paper, which expressed the government's concern about the state of British science - including its low appeal to school students - and its determination to give science a more attractive image. "The government says it is worried about people not going into science, but they seem to be doing the best they can to put them off even more", says Valerie Ellis, assistant general secretary of the Institute of Professionals Managers and Specialists (IPMS), whose members include scientists from many government laboratories.

Scientists have already had salary increases held back by the government. This

year - like all public employees - they have been limited to a rise of 1.5 per cent, considerably less than the anticipated rate of inflation for the year. If Clarke sticks to his word, next year's situation will be worse.

Particularly hard hit, according to Ellis, will be those in certain grades (such as chief scientific officers) who were to have had a salary review next year to bring them up to comparable salaries in the private sector.

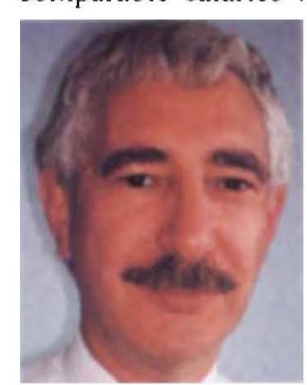

AUT president David Triesman warns of a crisis in universities. numbers, staff in the "old" universities are today teaching 46 per cent more students than they were six years ago; but their salaries have actually decreased by one per cent in real terms over the same period.

AUT officials - in common with the Committee of Vice Chancellors and Principals - also argue that the decision to continue to hold down salaries comes at a particularly sensitive time. Many university

\section{Germany to boost R\&D in small companies}

Berlin. Germany's ministry of research and technology (BMFT) has launched a new programme designed to boost rescarch and development in small and medium sized companies employing up to 500 employees.

Particular emphasis will be placed on companies in the new Länder of what was formerly East Germany. But a report from Berlin's Centre for Social Science Research (CSSR) criticizes previous programmes run by the BMFT with similar goals, claiming that their success has been limited by the general underfinancing of the Länder's industrial base.

The new BMFT programme runs until 1997, and will have a total budget of DM200 million ( $\$ 320$ million). The money will be available to support collaborative projects between two or more companies, or between a company and a research institute. It can also be used to enable company employees to spend short periods working in a research institute.

East German companies will be expected to match the money put up by the ministry with their own funds. Those from the old Länder will have to provide more - be- tween 60 and 75 per cent - of the project money themselves.

The CSSR has conducted assessments of many government projects, particularly in the new Länder. In a report issued last month, it warns that previous programmes intended to bolster industrial R\&D in the former DDR have in fact done little to stop its steady decline.

At the request of the BMFT, the centre investigated the results of two special programmes funded by the ministry which came to an end last year. One, costing DM50 million so far, is aimed at increasing the number of research staff in industrial companies. The other (at DM62 million) to help companies develop their ability to carry out contract research.

Both programmes were surprisingly successful in their immediate aims, says the centre. But despite this, it adds, the eastern German companies often did not have the capital to move new products through development, effectively wasting the research effort. And overall industrial research capacity continues to fall.

Alison Abbott teachers are rapidly approaching retirement, but faculties lack the funds to make the new appointments needed to ensure an orderly succession of good academic staff.

"Taken together with the continuing fall in morale among researchers, the chancellor's announcement could produce one of the most acute crises that we have seen in British universities this century", says AUT president David Triesman.

Officially, Britain's research councils say they are withholding comment until the formal announcement of the terms for next year's pay deal with public sector employees, which will be unveiled in the autumn budget statement at the end of November. Behind the scenes, science administrators are also hoping to put pressure on Whitehall (and sympathetic ministers) to convince the Treasury that a salary freeze on scientists would be counter-productive in the long-term. Meanwhile, the IPMS is planning a series of demonstrations later in the autumn to take their case to the public.

David Dickson

\section{UK graduates a bridge to Japan?}

London. British companies should consider sending their graduate recruits to Japan for a year before they start work in Britain. The suggestion comes from the chairman of a committee set up by the Office of Science and Technology (OST) to advise the government on how to strengthen its scientific and technological links with Japan.

Sir Geoffrey Allen, a former chairman of the Science and Engineering Research Council, and now an adviser to the Japanese company Kobe Steel, said last week that such a move would help build a greater awareness in British industry of the reasons for Japan's industrial success.

It would also avoid disputes over the protection of intellectual property that frequently plague such arrangements. At present, managers are often reluctant to send their scientists and engineers to work with companies in Japan because of the knowledge they inevitably take with them.

Sir Geoffrey was speaking shortly before this weekend's departure of William Waldegrave, the science minister, for a five day visit to Japan. One of the main purposes of the visit will be to encourage more Japanese companies to set up research and development facilities in the UK.

The new advisory committee is made up of ten academics and industrialists, each with personal experience of Japan. According to OST officials, the committee will be responsible for analysing and making recommendations on the strategic issues concerning the development of closer scientific and technological links. 